\title{
A FILOSOFIA JURÍDICA DE DWORKIN E A INDENIZAÇÃO PUNITIVA: FUNDAMENTOS JUSFILOSOFICOS PARA A PUNITIVE DAMAGE EM MATÉRIA AMBIENTAL
}

\author{
Fernando Barotti dos Santos* \\ Émilien Vilas Boas Reis ${ }^{* *}$
}

\begin{abstract}
Resumo: O artigo é um estudo de caso à luz da filosofia jurídica de Dworkin. Tratou-se de recursos especial repetitivo do Superior Tribunal de Justiça, que inviabilizou a utilização da indenização punitiva, espécie de responsabilidade civil derivada da common law. A pesquisa busca analisar o voto vencedor, propondo argumentos com uso da tese do ativismo judicial sobre a possibilidade de utilização da punitive damage em matéria ambiental. $\mathrm{O}$ presente trabalho foi desenvolvido sob a metodologia jurídico-teórica e raciocínio dedutivo, com pesquisa bibliográfica e jurisprudencial. Conclui-se que por meio do ativismo judicial há possibilidade de aplicação da indenização punitiva em matéria ambiental.
\end{abstract}

Palavras-chave: Ativismo Judicial; Filosofia Jurídica; Meio Ambiente; Indenização Punitiva; Princípios Ambientais.

\section{DWORKIN'S LEGAL PHILOSOPHY AND PUNITIVE INDEMNIFICATION: JUSPHYLOSOPHICAL FOUNDATIONS FOR PUNITIVE DAMAGE IN ENVIRONMENTAL MATTERS}

\begin{abstract}
This paper is a case study from Dworkin's legal philosophy. These are special repetitive resources of the Superior Court of Justice, which made it impossible to use punitive damages, a kind of civil liability derived from common law. The research seeks to analyze the winning vote, proposing arguments using the thesis of judicial activism on the possibility of using punitive damages in environmental matters. The present work was developed under the juridical-theoretical methodology and deductive reasoning, with bibliographical and jurisprudential research. It is concluded that through judicial activism there is a possibility of applying punitive damages in environmental matters.
\end{abstract}

Keywords: Judicial Activism; Legal Philosophy; Environment; Punitive Damage; Environmental Principles.

\section{INTRODUÇÃO}

\footnotetext{
* Advogado. Mestrando em Direito Ambiental e Desenvolvimento Sustentável pela Escola Superior Dom Helder Câmara. Graduado em Direito pela Escola Superior Dom Helder Câmara. Membro do grupo: Por uma justiça ambiental: estudos de Filosofia do Ambiente e de Ética Ambiental para um novo Direito Ambiental. E-mail: fernando_barotti@hotmail.com.

${ }^{* *}$ Pós-doutorado em filosofia pela Universidade do Porto. Doutorado em filosofia pela Pontifícia Universidade Católica do Rio Grande do Sul. Mestrado em filosofia pela Pontifícia Universidade Católica do Rio Grande do Sul. Graduação em filosofia pela Universidade Federal de Minas Gerais. Professor adjunto da Escola Superior de Ensino Dom Helder Câmara, em nível de graduação e mestrado. Coordenador do grupo "Pensar a cidade: seus aspectos ambientais, jurídicos e sociais”- Dom Helder. E-mail: mboasr@yahoo.com.br.
}

Revista Brasileira de Filosofia do Direito| e-ISSN: 2526-012X| Porto Alegre | v. 4 | n. 2 |

p. $01-20$ | Jul/Dez. 2018 
O artigo trata da decisão do Superior Tribunal de Justiça, no recurso especial repetitivo, representando conjunto de recursos especiais que tenham mesmo fundamento, julgado em 2014, negando a aplicação da indenização punitiva no caso concreto. O caso diz respeito ao dano ambiental por vazamento de amônia no estado de Sergipe, gerando reflexos ao Meio Ambiente, aos grupos viventes e dependentes da região, bem como à coletividade, tendo em vista ser o Meio Ambiente objeto jurídico detentor de uma complexidade que será abordada no artigo.

A pesquisa debruça-se sobre a aplicação da teoria do valor de desestímulo, derivação da responsabilidade civil da common law, que extrapola o valor do dano moral para punir o agente, inviabilizada pelo voto vencedor sob a justificativa da inadequação dos institutos ao direito pátrio. Verifica-se, contudo, a ineficiência de institutos de responsabilização ambiental no ordenamento jurídico brasileiro, o que exige novas ferramentas de punição, pois as atuais não são efetivas, abrindo espaço para a importação de ferramentas jurídicas que objetivem reprimir o dano.

Pretende-se estudar a aplicação da punitive damages no sistema legal brasileiro por atuação proativa do judiciário, e buscando responder se por meio do ativismo judicial há possibilidade de aplicar a indenização punitiva contra quem causa dano ambiental. O marco teórico da pesquisa funda-se na filosofia jurídica de Ronald Dworkin (1931 - 2013) e sua teoria interpretativa do Direito, analisando a melhor descrição dos conjuntos de regras e as decisões jurisdicionais. O filósofo apresentado será utilizado para estabelecer uma argumentação contrária ao exposto do recurso especial $n^{\circ} 135.4536 / \mathrm{SE}$, que não permitiu a aplicação da teoria, expondo a existência de uma conduta proativa histórica do Poder Judiciário brasileiro em matéria de garantias fundamentais.

Justifica-se o estudo devido a inaptidão da proteção ambiental, tendo como consequência a ineficácia da responsabilização de agentes degradadores, necessitando de instrumentos, como a indenização punitiva, para inibir o dano. O Meio Ambiente, por ser coletivo e difuso, necessita de instrumentos eficazes à sua proteção, já que os modelos atuais não produzem os efeitos necessários para a redução dos impactos ambientais. Dessa forma, é cabível a utilização da indenização punitiva por força interpretativa jurisdicional.

$\mathrm{O}$ artigo se divide em três itens: no primeiro será abordado a teoria dworkiana do ativismo judicial e, o ativismo judicial no brasil; no segundo será abordada a responsabilidade civil a partir da explanação sobre o dano moral e suas vertentes indenizatória reparatória e 
punitiva; por fim, apresenta os fundamentos do relator em desfavor a aplicação da indenização punitiva sob à luz do ativismo judicial.

A pesquisa será explicativa e descritiva com uso de jurisprudência e bibliografia, com objetivo de entender o ativismo judicial. Ao mesmo tempo, a abordagem do problema será qualitativa e método dedutivo analisando o emprego da punitive damages, no ordenamento jurídico brasileiro, por força do ativismo judicial.

\section{A CONCEPÇÃO JUSFILOSÓFICA DO ATIVISMO JUDICIAL EM DWORKIN}

O "Ativismo judicial" é uma terminologia inaugurada no artigo do historiador Arthur Schlesinger (1947) sobre a Suprema dos Estados Unidos, estabelecendo críticas ao posicionamento da Corte à época. O termo lançado passa a qualificar, posteriormente, a atuação da Corte Warren, conhecida pelas decisões que buscavam efetivar garantias fundamentais.

Para Barroso (2012), o período da Corte Warren foi o mais intenso em assegurar direitos estabelecidos na Constituição Americana, proporcionando uma revolução profunda e silenciosa, conduzida por uma jurisprudência progressista em matéria de direitos fundamentais.

Entende-se, portanto, por Ativismo judicial como

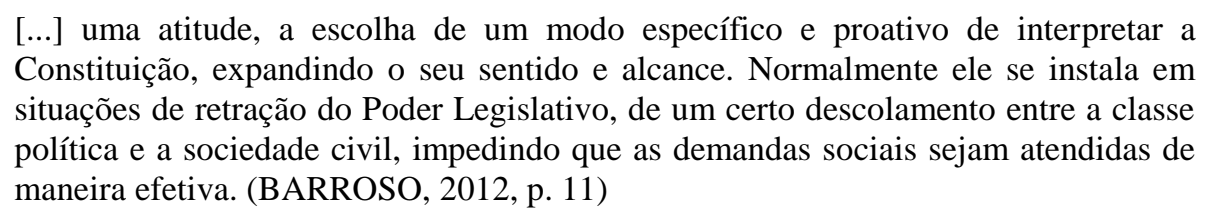

É a forma que um tribunal toma suas decisões, de modo a expandir o alcance do texto da Constituição. Não há nessa ampliação textual a mudança estética do texto, apenas uma mudança interpretativa do mesmo, com objetivo de garantir que o exposto no escrito seja estabelecido. A proposta do Ativismo judicial é de estender a participação do Judiciário, a fim de se concretizar os preceitos constitucionais, por meio da interpretação constitucional, cabendo ao magistrado promover as garantias estabelecidas, não podendo eximir-se da responsabilidade de apreciação do caso a que for levado.

Para Dworkin o posicionamento ativo do juiz é um dever, uma responsabilidade, que não pode ser abandonada pois deve promover, por esse meio, a justiça. Mesmo não possuindo 
legitimação política, representam a justiça, atores da efetivação e integridade do direito, estabelecendo que:

\begin{abstract}
Nosso sistema constitucional baseia-se em uma teoria moral específica, a saber, a de que os homens têm direitos morais contra o Estado. As cláusulas difíceis [...] como as cláusulas do devido processo legal e da igual proteção, devem ser entendidas como um apelo a conceitos morais [...]. Portanto, um tribunal que assume o ônus de aplicar tais cláusulas plenamente como lei deve ser um tribunal ativista, no sentido de que ele deve estar preparado para formular questões de moralidade política e dar lhes uma resposta. (DWORKIN, 2014, p. 231)
\end{abstract}

Dworkin critica o pensamento jurídico de Hart (1907-1992), um positivista, seu professor e seu maior crítico, com quem estabeleceu diálogos proveitosos sobre a ideia de justiça. O jusfilósofo questiona o positivismo, pois ele "[...] rejeita não uma metafísica patentemente absurda, mas um estilo perfeitamente prático de julgamento. [...] a crítica positivista tornou-se a arma de juristas conservadores na sua oposição ao uso de nossa Constituição para proteger direitos individuais contra o Estado" (DWORKIN, 2007, p. 25).

A proposta de Dworkin (2010) liga-se à melhor interpretação do direito em sintonia com a equidade, justiça e o devido processo legal, em prol de uma melhor adequação e justificação das práticas jurídicas como um todo. O magistrado tem a tarefa de cumprir a lei, mas devendo assumir uma postura de interpretação ousada dos princípios constitucionais, tais como, justiça, moral, dignidade da pessoa e igualdade na defesa dos interesses sociais, para isso, defende um conceito de interpretação:

Uma interpretação tem por finalidade mostrar o que é interpretado em sua melhor luz possível e uma interpretação de qualquer parte de nosso direito deve, portanto, levar em consideração não somente a substância das decisões tomadas por autoridades anteriores, mas também o modo como essas decisões foram tomadas: por quais autoridades e em que circunstâncias. (DWORKIN, 2014, p. 306)

A postura proativa concebida por Dworkin (2014) é por ele denominada "contra majoritária" ou ativista, visando afastar os efeitos de leis injustas e a difusão delas quando em desfavor das minorias. Por isso, cabe ao julgador aderir à postura ousada em prol das garantias constitucionais, pois, é aquele que irá se debruçar nas leis para interpretá-las e dar a resposta correta. Nesse sentido, o jusfilósofo provoca:

[...] em algum sentido, o direito se altera por meio de decisões judiciais, assim como pela legislação explícita. Desse modo, os juízes sempre descrevem o direito como diferente daquilo que as pessoas esperavam que ele antes fosse, e usam sua descrição singular para decidir o próprio caso no qual ela está anunciada [...] tais mudanças não são realmente mudanças, mas, pelo contrário, descobertas de uma 
identidade subjacente, de modo que um juiz que pronuncia uma nova norma pode estar, em verdade, descrevendo o direito existente de uma forma mais acurada (DWORKIN, 2007, p. 15).

Para Dworkin (2010), o papel dos julgadores é de concretização dos direitos sociais numa interpretação construtiva. Os julgadores devem se assemelhar a romancistas "devem criar em conjunto, até onde for possível, um só romance unificado que seja da melhor qualidade possível" (DWORKIN, 2014, p. 276). A ideia de romance em cadeia propõe para o julgador atentar-se às decisões anteriores, dando continuidade à construção jurisprudencial ou afastando teses que não se apresentem adequadas à situação social da época vigente, sempre promovendo a justiça e os valores morais.

A situação faz com que o magistrado coloque frente o caso concreto as vontades da sociedade democrática, no intuito de promover as garantias sociais diante das ingerências e omissões do Legislativo e Executivo, cabendo a eles a função de rever suas decisões ao longo do tempo de forma a evitar decisões distorcidas, dessa forma:

Devem desenvolver princípios de legalidade, igualdade e assim por diante, revê-los de tempos em tempos à luz do que parece ser a visão moral recente da Suprema Corte, e julgar os atos do Congresso, dos Estados e do Presidente de acordo com isso (DWORKIN, 2014, p. 215).

É importante a diferenciação entre regras e princípios, enquanto a primeira (regras) "[...] são aplicáveis à maneira do tudo-ou-nada." (DWORKIN, 2014, p. 39), dessa forma, observando as regras de antinomias jurídicas aparente, caso exista conflito entre regras, uma delas não pode ser válida. No caso dos princípios o autor descreve:

Denomino "princípio" um padrão que deve ser observado, não por que vá promover ou assegurar uma situação econômica, política ou social considerada desejável, mas porque é uma exigência de justiça ou equidade ou alguma outra dimensão da moralidade. (DWORKIN, 2014, p. 36)

É importante observar que o jusfilósofo afasta a ideia de arbitrariedade do juiz, devendo ser observadas os princípios e a Constituição. Os princípios são normas axiológicas, sobretudo, limitadoras ao poder de decisão do juiz, impondo-lhe que mantenha sua decisão dentro de valores constitucionais. Sem que estabeleça sua vontade ou interesses na decisão a proferir.

Em auxilio ao banimento de decisões arbitrárias, Dworkin (2010) recorre à figura mitológica de Hércules, encarnado em um juiz que possui a capacidade e a sabedoria sobrehumanas, consistindo na metáfora máxima da ideia de justiça, interpretação e aplicação do 
direito. Ele serve como referência de julgador com condições plenas e perfeitas, para dar a melhor das interpretações à tutelar direitos fundamentais. Assim, tem a figura de Hércules o dever de

[...] construir um esquema de princípios abstratos e concretos que forneça uma justificação coerente a todos os precedentes do direito costumeiro e, na medida em que estes devem ser justificados por princípios, também um esquema que justifique as disposições constitucionais e legislativas (DWORKIN, 2010, p. 182).

Os juízes em situação normal devem buscar na figura mitológica o compromisso pela melhor e adequada aplicação do direito, estando sempre voltados para o compromisso constitucional e a promoção de liberdade, das garantias e dos valores morais. A Constituição para Dworkin (2010) não é um mero instrumento normativo de uso ou desuso dos julgadores, é, na verdade, a base para o desenvolvimento da justiça e consolidação dos direitos fundamentais. É dela que o magistrado deverá extrair o princípio que solucionará o caso que esteja julgando.

É a partir da interpretação da constitucional que se permitirá o ativismo judicial, extraindo-se dela instrumentos ou princípios que possibilitarão as conquistas e a manutenção das pretensões emanadas da sociedade. Mais do que isso, a decisão judicial será válida e eficaz por que se justifica tanto em casos fáceis ou difíceis na integridade do direito, ou sua coesão sistêmica de interpretação, em suas teses jurisprudenciais, os princípios, assim,

[...] o Direito como Integridade, além de uma interpretação específica da prática jurídica, funciona também, ele mesmo, como um programa interpretativo. O Direito como integridade não é apenas um fruto da interpretação, mas é também uma fonte de inspiração da interpretação mesma; pede a seus juízes que continuem, em sua prática, a interpretar o material que ele mesmo afirma ter interpretado com sucesso e se apresenta como a continuidade e como a origem das interpretações mais detalhadas que recomenda (MACHADO, 2016, p. 248).

Portanto, as decisões dos tribunais, devem ser pautadas na Constituição, em suas diretrizes, valores, princípios e regras, de tal maneira que qualquer questão levada a essa função estatal deve nortear-se na resposta mais próxima a sociedade. O programa do ativismo judicial em seu posicionamento contra majoritário precisa compreender a noção interpretativa e integradora do direito.

No Brasil o papel ativista do judiciário é observado desde a criação da República em 1889 no Supremo Tribunal Federal (STF). O ativismo da Corte ao decidir sua competência 
originária, em matérias referentes ao Habeas Corpus, evidencia a postura afirmativa das garantias fundamentais, criando a Doutrina Brasileira do Habeas Corpus.

[...] a doutrina brasileira do habeas corpus, caracterizada como uma ampliação das garantias fundamentais do cidadão no Brasil, é o embrião do mandado de segurança, que, portanto, tem sua origem associada à produção pretoriana do Supremo Tribunal Federal nos albores da República. Tanto é assim que, não raro, o mandado de segurança é apontado como criação genuinamente brasileira [...] (HORBACH, 2007 p.73).

A doutrina foi marco importante, um salto jurisprudencial no STF, contra atos de autoridades públicas. De acordo com Campos (2007), o tribunal progressivamente alargaria a competência de alcance do Habeas Corpus, objetivando o controle judicial em situações jurídicas não abarcadas por outras ações ou remédios constitucionais.

Contudo, é com a Constituição de 1988 que pode ser observada uma posição proativa dos tribunais com maior intensidade, onde foi incluído inovações em suas jurisprudências. A justificativa para tal atuação ocorre em razão do extenso rol de garantias constitucionais, e uma ampla competência do judiciário, internalizado pelo princípio da inafastabilidade de controle judicial ${ }^{1}$.

As causas do ativismo pós 1988 derivam da aplicação da Constituição em situações que não foram abordadas em seu texto, o que seria, "a imposição de condutas ou de abstenções ao Poder Público, notadamente em matéria de políticas públicas.” (BARROSO, 2012, p. 11). Podem ser citados os casos do julgamento da fidelidade partidária, da distribuição de medicamentos, a declaração de inconstitucionalidade de atos e leis e, mais recentemente, o julgamento de constitucionalidade e inconstitucionalidade do vigente Código Florestal.

Há a intensão coletiva de consolidar os direitos previstos na Constituição de 1988, entretanto, sobrevém uma crise institucional e política, com a promulgação do texto constitucional em 1988. Os interesses difusos e coletivos tornaram-se objetos de tutela jurídica para sociedade pelo judiciário para a construção do direito, “inevitável, portanto, a tendência ao estabelecimento de uma linha de tensão nas relações entre o Judiciário, de um lado e o Executivo e o Legislativo, de outro, entre a filosofia política da carta de 1988 e a agenda neoliberal" (VIANNA, 1999, p. 48).

\footnotetext{
${ }^{1}$ Art. $5^{\circ}, \mathrm{XXXV}$ - a lei não excluirá da apreciação do Poder Judiciário lesão ou ameaça a direito (BRASIL, 1988).
} 
Note-se que por organização constitucional, o Poder Judiciário é chamado para assumir a função também de freios e contrapesos ${ }^{2}$, com finalidade assecuratória de direitos e garantias sociais. Outrossim, consolida-se como importante representante da democracia. Com uso da interpretação da Constituição, o juiz deverá alcançar a melhor tese normativa possível, de forma que o ativismo jurídico possa ser útil às conquistas dos interesses sociais e ao direito.

\section{O DANO MORAL E A RESPONSABILIDADE CIVIL: A TEORIA DO VALOR DE DESESTÍMULO NO BRASIL}

Desde 1988, quando a Constituição Federal (CF/88) incluiu no texto a previsão da reparação civil por danos morais, a possibilidade da vertente reparatória da responsabilidade civil foi permitida, sem grandes questionamentos sobre sua aplicação. "As normas constitucionais também possibilitaram previsões legais expressas, pelo Código de Defesa do Consumidor (art. 6, VI e VII) e pelo Código Civil de 2002 (art. 186)" (ARAUJO FILHO, p. 331), dessa forma, além de constitucionalizado sistematicamente, o dano moral, em sua visão reparatória, ganhou espaço no ordenamento jurídico pátrio, bem como utilização.

Relativo ao texto constitucional, a indenização à honra foi estabelecida no art. $5^{\circ}$, incisos V e X CF/88; o mesmo no âmbito do Código Civil de 2002 (CC/02) em que foi adotado nos arts. 944 ao 954. Em ambas as leis, com o auxílio da doutrina e jurisprudência, observa-se que a indenização leva em conta a extensão do dano, a gravidade do agravo de ambas as partes e a capacidade de aporte financeiro do autor do dano.

Contudo, a projeção punitiva do dano moral é incipiente perto da intenção indenizatória, necessitando ainda de um aprofundamento teórico para sua harmonização e, posteriormente, aplicação no ordenamento jurídico brasileiro. A teoria do valor de desestímulo ou punitive damages (também chamadas de exemplary damages, vidictive damages ou smart money), ou ainda indenização punitiva, tem origens em países que adotam o sistema da common law como os Estados Unidos da América e o Reino Unido. A punitive damage caracteriza-se como "[...] quantia pecuniária, geralmente imposta por um corpo de jurados, como forma de sanção a um ato ilícito altamente reprovável, cuja função é a de punir o ofensor e de prevenir o cometimento de novos ilícitos futuros [...]" (SERPA, 2011, p. 26).

\footnotetext{
${ }^{2} \mathrm{O}$ sistema de freios e contrapesos visa evitar a produção de normas não democráticas, por isso, surge a ideia de que só o poder controla o poder, por isso, onde cada poder é autônomo no exercício de sua função precípua, esse, deve ser controlado pelos outros poderes, sendo então independentes e harmônicos entre si (Nota dos autores).
} 
A função punitiva do dano moral é mais clara e mais utilizada, pois

\begin{abstract}
numa sociedade bastante complexa e interligada como é a norte-americana, já se fazia absolutamente necessária uma maior proteção às vítimas de atos ilícitos, isto porque quanto maior o relacionamento entre os indivíduos, quanto mais sofisticados os elementos materiais colocados à sua disposição, tanto maior o risco, e uma das soluções por certo é, ao invés de dar proteção paternalista ao ofensor, demonstrarlhe que as consequências do seu ato danoso serão pesadas (CASILLO, 1987, p. 61 apud, ARAUJO FILHO, 2015, p. 333).
\end{abstract}

A tese da indenização punitiva deriva da responsabilidade civil prevista no ordenamento jurídico, possuindo o dano como elemento principal, que além da reparação, ressarcimento ou reequilíbrio patrimonial do lesado, visa a punição pedagógica. A responsabilidade, portanto, ocorre após o injusto dano.

Para Martins-Costa e Pargendler (2005) há um emprego duplo da punitive damages: punir o autor do dano e, ao mesmo tempo, minimizar a prática de comportamentos lesivos. Permite-se, dessa maneira, estabelecer uma soma adicional, extrapolando "independentemente de eventual indenização compensatória a que possa fazer jus o ofendido" (SERPA, 2011, p. 26) o valor arbitrado a quem tem o direito.

A forma preventiva e punitiva se dá "[...] na soma em dinheiro conferida ao autor de uma ação indenizatória em valor expressivamente superior ao necessário à compensação do dano, tendo em vista a dupla finalidade de punição (punishment) e de prevenção pela exemplaridade da punição [...]” (MARTINS-COSTA; PARGENDLER, 2005, p. 16).

Há quem o coloque a possibilidade da aplicação da indenização punitiva em casos de danos à sociedade ou à coletividade "isso porque, conforme ensinamento de Antônio Junqueira de Azevedo (2004) [...] o dano social é uma lesão não só à vítima direta do dano, mas principalmente à sociedade como um todo, no seu nível de vida" (LEITE, 2009, p. 1).

Para valer-se da teoria do desestímulo, aplica o agente um alto valor ao dano moral que é "uma lesão a um interesse existencial concretamente merecedor de tutela" (FARIAS; BRAGA NETTO; ROSENVALD, 2015 p. 296), em posição semelhante, porém, mais proativa, o STJ propõe que conceito de dano moral “[...] deve levar em consideração, eminentemente, a dignidade da pessoa humana - vértice valorativo e fundamental do Estado Democrático de Direito - conferindo-se à lesão de natureza extrapatrimonial dimensões mais amplas, em variadas perspectivas" (BRASIL, 2014a).

Ressaltando as características da indenização punitiva, situações que envolvam direitos difusos e coletivos, como o direito do consumidor e o Meio Ambiente, permitir-se-ia 
a aplicação, nestes casos, majorando o valor do dano moral. "Em nosso país praticamente toda a discussão a respeito das aludidas funções de punição e prevenção se insere no contexto da condenação ao pagamento de indenização por danos morais” (SERPA, 2011, p. 13).

Como se trata de indenização extracontratual e imaterial, não há valor préestabelecido, cabendo a quem for estabelecer o valor do dano, o encargo em arbitrar o quantum da compensação. A arbitragem levará em conta os fatores relativos ao caso concreto, também não se escusando de observar os princípios, pois, como se verifica na teoria dworkiana, devem essas categorias de normas serem observadas.

Destaca-se dentro da responsabilidade civil punitiva o princípio da prevenção, uma vez que, possibilita a utilização da indenização punitiva, não se vinculando ao dano remediado, mas a proteção do bem existente. De tal modo, este princípio remete a ideia de um direito proativo (FARIAS; BRAGA NETTO; ROSENVALD, 2015), inserido no contexto da ousadia jurisdicional defendida por Dworkin.

Tratando de princípios, merece atenção a dignidade da pessoa, na sua dimensão comunicativa, de forma a ser observado os aspectos da coletividade, para a eficácia dos direitos fundamentais, "[...] permitindo a incidência direta ou indireta de princípios constitucionais nas relações civis [...]" (FARIAS; BRAGA NETTO; ROSENVALD, 2015, p. 22). A exemplo, o direito ao Meio Ambiente ecologicamente protegido, seria resguardado por este princípio, devendo buscar enfraquecer a ocorrência do dano.

Assim, encontra-se no juiz o dever de estabelecer a indenização do dano moral, buscando não somente o valor compensatório do dano, mas o valor que antepare a ocorrência de novos danos à luz dos princípios da precaução e da dignidade da pessoa.

$\mathrm{Na}$ doutrina e nos tribunais brasileiros vêm-se tentando esse modelo jurídico de responsabilização dos países de common law. O STJ, em julgados, reconhecera a função punitiva da indenização, afirmando que " $O$ valor do dano moral tem o escopo de atender a sua dupla função: reparar o dano e punir o ofensor para que não volte a reincidir (elemento pedagógico punitivo)" (BRASIL, 2009, p.5). Em mesmo sentido tem-se os Resp. 715320/SC; Resp. 792416/SP; Resp. 332589/MS.

Venosa (2009), citado por Machado, já previa a aplicação do instituto no ordenamento jurídico brasileiro, afirmando ser tendência universal indenizar todo e qualquer dano, pois, este é um elemento de insegurança social, indicando que "[...] no campo do dano extrapatrimonial, quando a indenização pode assumir caráter punitivo [...]" (2018, p. 417), 


\title{
A FILOSOFIA JURÍDICA DE DWORKIN E A INDENIZAÇÃO PUNITIVA: FUNDAMENTOS JUSFILOSOFICOS PARA A PUNITIVE DAMAGE EM MATÉRIA AMBIENTAL
}

que o valor estabelecido não tenha relação com o prejuízo. Em mesmo sentido, Bittar (1993), indicava a possibilidade do punitive damages no ordenamento jurídico pátrio:

\begin{abstract}
[...] vem-se cristalizando orientação na jurisprudência nacional que, já de longo tempo, domina o cenário indenizatório nos direitos norte-americano e inglês. É a da fixação de valor que serve como desestímulo a novas agressões, coerente com o espírito dos referidos punitive ou exemplary damages da jurisprudência daqueles países. Em consonância com essa diretriz, a indenização por danos morais deve traduzir-se em montante que represente advertência ao lesante e à sociedade de que não aceita o comportamento assumido, ou o evento lesivo advindo. Consubstanciase, portanto, em importância compatível com o vulto dos interesses em conflito, refletindo-se, de modo expressivo, no patrimônio do lesante, a fim de que sinta, efetivamente, a resposta da ordem jurídica aos efeitos do resultado lesivo produzido. Deve, pois, ser quantia economicamente significativa, em razão das potencialidades do patrimônio do lesante (BITTAR, 1993, p. 232-233).
\end{abstract}

A teoria do desestímulo ganha força e torna-se ferramenta no Direito do Consumidor, sendo utilizada na punição de quem causa lesão, em vista da fragilidade existente na relação de consumo, sendo igualmente um direito difuso, coletivo e individual homogêneo. Busca-se aplicar igual tese nas questões ambientais, na proteção constitucional ao Meio Ambiente, é nescessario, portanto, instituir instrumento aptos a desestimular o dano, principalmente os graves, sob os mesmo argumentos, pois ambos direitos são de terceira geração (BOBBIO, 2004). Assim, desde que auxilie o direito a reduzir o dano ou a preveni-lo, não há vedação de qualquer insittuito a ser utilizado no ordenamento jurídico.

Analisando ainda de forma sistemática, percebe-se na Lei da Ação Civil Publica no 7.347/85 a previsão para responsabilizar moralmente o sujeito danoso, podendo, assim, estabelecer a punitive damages por meio do dano moral coletivo. A coletividade é quem sofre a lesão, dessa maneira, é o fundamento, juntamente com a ideia de que o bem ambiental é de uso comum, pouco importando a condiçao economica do poluido, na aplicação elevada do valor reparatório.

Outra argumentação favorecendo a aplicabilidade da teoria do desestímulo, ocorre pela interpretação constitucional, teleológica e sistêmica dos referidos artigos da Constituição e do Código Civil (CC/02) (art. 5, V e X, CF/88; arts. 944 ao 954, CC/02). Em se tratando da interpretação dos artigos constitucionais e sua complexidade, têm-se que sua função finalística é guardar, promover, assegurar e limitar os direitos para que seja mantido o bemestar da coletividade.

Na lei civil intepreta-se os artigos da responsabilidade civil por dano moral, de forma a integrar os preceitos da Constituição e, igualmente, visualizar todo o ordenamento jurídico 
presente, para a manutenção das relações socias. Percebe-se, assim, que nenhuma das duas normas expostas possui vedação à sua implementação e uso da reparação moral em sua ótica punitiva, cabendo ao julgador aplicar de forma objetiva e adequada a punitive damage, entendendo a complexidade e o objeto jurídico em julgamento.

A tese interprettiva dos princípios de Dworkin, bem como o a integridade do dirieto pela interpretação sistêmica, permitem averiguar na teoria do desestimulo a possibilidade e uso desse intrumento no ordenamento jurídico braisleiro.

A Punitive Damages tenta trazer ao caso concreto, não somente a indenização do lesionado, mas visa mostrar, para quem está prejudicando terceiros, que sua condulta não pode conservar-se no tempo. Faz-se visualizar, portanto, que a lesão não atige somente a uma única pessoa, mas uma coletividade ou grupos, como no caso das questões referidas ao Meio Ambiente. Ao julgador cabe avaliar as condições fáticas para punir, verificada a fragilidade do objeto, o agente danoso e os atingidos, para diminuir os danos sofridos.

Assim, no item a seguir será estudado a decisão do Superior Tribunal de Justiça que negou a aplicação da indenização punitiva, aplicando-se a tese do ativismo judicial em Dworkin para contra argumentar o exposto pelo Ministro relator em seu voto vencedor.

\section{PUNITIVE DAMAGES, ATIVISMO JUDICIAL E MEIO AMBIENTE: A DECISÃO DO STJ NO RECURSO ESPECIAL DO CASO RIO SERGIPE}

A tese de Dworkin visa a instrumentalidade e a viabilidade da decisão judicial, quando em suas mãos há casos difíceis de decisão, o juiz pode utilizar os princípios para compor seu julgamento, a fim de atribuir a resposta correta ao caso. $\mathrm{O}$ fato a ser apresentado, nesse artigo, mostra-se como uma dessas difíceis decisões judiciais, pois envolve uma complexidade de sujeitos, argumentos e direitos que serão apresentados a seguir. Será traçado uma possibilidade de aplicação da indenização punitiva sobre questões ambientais, visto ser necessária a atenção e tratamento para sua conservação e manutenção do bem jurídico e direito fundamental.

Explanados os conceitos do ativismo judicial e da indenização punitiva, passa-se a observação do recurso interposto perante o STJ, abordando a questão do dano moral e sua função punitiva, a punitive damages. 
O caso exposto foi julgado em 2014 pelo tribunal superior, em sede recurso repetitivo, representando grupo de recursos especiais detentores de teses idênticas, com os seguintes fatos:

\begin{abstract}
Narra que, no dia 5 de outubro de 2008, a indústria Fertilizantes Nitrogenados de Sergipe - FAFEN, subsidiária da requerida, deixou vazar para as águas do rio Sergipe cerca de 43.000 (quarenta e três mil) litros de amônia, fato que resultou em dano ambiental, provocando a morte de peixes, camarões, mariscos, crustáceos e moluscos com a consequente quebra da cadeia alimentar do ecossistema fluvial local [...] aduzindo que o acidente causou danos também aos pescadores, em especial aos artesanais, por não terem condições de pescar em outra localidade e também por ter ocorrido em época de maior abundância de pescados (BRASIL, 2014b, p. 1).
\end{abstract}

O fundamento do recurso perante o STJ teve base no art. 105, III, alíneas "a" e "c" da Constituição Federal de 1988, tratando das hipóteses de interposição dos recursos especiais em casos de decisões contrárias a tratados, leis federais ou, ainda, que tenham sua vigência negada e interpretação de lei federal divergente. O Ministro relator, em seu voto, informa que o dano ambiental foi comprovado por laudos periciais, indicados na ação civil pública, caracterizando a responsabilidade da empresa exploradora, colocando-a na posição de mantenedora da proteção ambiental (BRASIL, 2014b).

O Ministro relator em seu primeiro argumento para inviabilidade da indenização punitiva arguiu quanto ao arbitramento dos danos morais em caráter punitivo que "[...] a função punitiva cabe ao direito penal e administrativo, propugnando que os principais critérios para arbitramento da compensação devem ser a intensidade do risco criado e a gravidade do dano [...]" (BRASIL, 2014b, p. 15). O fundamento oferecido sugere que a responsabilidade civil se atribui apenas em caráter reparador, ou seja, recompor a lesão sofrida.

A afirmativa do voto parece equivocada, uma vez que a punição não cabe exclusivamente a alçadas penais e administrativas. A responsabilidades possui diferentes naturezas, de acordo com o ramo do direito que se observa, permitindo, até mesmo, a responsabilização tripla, como é o caso do servidor público que quando se omite ou prática ato infracional pode ser punido nas três esferas. Deve-se observar a distinção das responsabilidades e o objeto de cada uma. A primeira, nota a existência do dolo ou culpa em causar a lesão vinculados a um tipo penal a se enquadrar; a segunda, por sua vez, verifica a ilegalidade administrativa do ato praticado, constatado pelo agente munido do poder de 
polícia. A responsabilidade civil atenta-se ao descumprimento de uma obrigação e ao dano causado, havendo a recomposição da obrigação ou reparação.

Mas há possibilidade de admissão da punição na seara civil, casos como o devedor de alimentos, que permite, até mesmo, sua prisão; ou como suscitado no Resp. 1.087.561/RS (Informativo 609 do STJ), uma indenização punitiva, em caráter pedagógico, para quem descumpre os deveres de assistência material ao menor (um movimento ativista do tribunal superior). Observa-se que a lei e a jurisprudência convalidam oportunidades de punição do sujeito incidente em ilícito civil; apesar de serem ligados a uma responsabilidade subjetiva, diferentemente da que é dada ao Meio Ambiente. Expõe-se que os exemplos apresentados infringem direitos fundamentais, pessoas e bens vulneráveis.

Tendo em vista ser o Meio Ambiente um objeto jurídico difuso e coletivo, não podendo determinar parte do bem ou pessoa afetada, não se pode definir um valor de ofensa moral que não represente o tamanho do bem (MACHADO, 2018). Encontra-se, portanto, uma lacuna interpretativa para a indenização punitiva. Ressalta-se que em matéria ambiental o legislador opta pela teoria objetiva, excluindo a comprovação da culpa, prescindindo somente de caracterização do nexo de causalidade e o dano.

A responsabilidade deriva do princípio com mesmo nome, o princípio da responsabilidade, garantida no art. 225 da $\mathrm{CF} / 88$, como forma de controle ao dano ambiental, em que impere a conciliação os direitos dos homens e seus deveres com os seus iguais (MACHADO, 2018). Atentando ao texto, não há, contudo, vedação para estabelecer o dano moral punitivo, nem a legislação infraconstitucional estabelece esta vedação, pois existe o interesse de proteger a coletividade:

Qualquer violação do Direito implica a sanção do responsável pela quebra da ordem jurídica. A lei Fundamental Brasileira estabelece, no $\S 3^{\circ}$ do artigo 255, a responsabilidade por danos ao maio ambiente [...] restou delegada para a legislação ordinária que a definiu como objetiva (ANTUNES, 2015, p. 52).

Há, portanto, a possibilidade do magistrado, se devido, aplicar o dano moral e majorá-lo para que detenha uma função punitiva. Dessa forma, partindo de uma aplicação e interpretação constitucional do princípio da responsabilidade por um método dworkiano, poderia ter o julgador encontrado abertura para um uso da indenização punitiva.

Em outro momento de seu voto o relator argumenta: 
Nessa toada, conforme consignou o Ministro Cesar Asfor Rocha no Resp. 214.053/SP, "para se estipular o valor do dano moral devem ser consideradas as condições pessoais dos envolvidos, evitando-se que sejam desbordados os limites dos bons princípios e da igualdade que regem as relações de direito, para que não importe em um prêmio indevido ao ofendido, indo muito além da recompensa ao desconforto, ao desagrado, aos efeitos do gravame suportado" [...] Com efeito, na fixação da indenização por danos morais, recomendável que o arbitramento seja feito com moderação, proporcionalmente ao grau de culpa, ao nível socioeconômico dos autores, e, ainda, ao porte da empresa recorrida [...]. (BRASIL, 2014b, p. 17).

O Ministro relator não se atenta ao fato de que o Meio Ambiente não é objeto ordinário de direito, pois tem como titular a coletividade “[...] o direito ao Meio Ambiente entra na categoria de direito difuso, não se esgotando numa só pessoa, mas se espraiando para uma coletividade indeterminada" (MACHADO, 2018, p. 153), apresentando indivisibilidade, impedindo a oposição de "condições pessoais" que privilegiem a não responsabilização do agente. Diversas vezes no "banco dos réus" estão empresas de porte, que empreendem de forma exaustiva o Meio Ambiente, obtendo lucro com a exploração, sem se preocupar com o espaço degradado. Deste modo, o juiz deve observar o princípio da reparação.

O princípio volta-se para a indenização decorrente de atividades que causem danos ambientais, pois esse afeta não só uma pessoa, mas indeterminados sujeitos de direitos. Resgata Machado a noção da coletividade, ao citar a Declaração de Estocolmo:

Já no "Preâmbulo" da Declaração de Estocolmo, no 7, consta: "atingir tal fỉm, em relação ao Meio Ambiente, exigirá a aceitação de responsabilidade por parte de cidadãos e comunidade, e por empresas e instituições, em todo os níveis, participando todos de maneira justa nos esforços comuns". (MACHADO, 2018, p. 122)

Mais uma vez, encontra o julgador a permissão em aplicar a teoria do desestímulo diante do caso concreto com a intenção de dirimir o dano. Tendo em vista que a proteção do Meio Ambiente é dever, assume a obrigação de reparar ou indenizar o agente que causa o dano.

Por fim, outro argumento apresentado é de que “[...] é preciso diversos fatores para se alcançar um valor adequado ao caso concreto, para que, de um lado, não haja enriquecimento sem causa de quem recebe a indenização e, de outro lado, haja efetiva compensação pelos danos morais [...]” (BRASIL, 2014b, p. 17), não há, contudo, de ser considerado este argumento.

Sobre este enriquecimento, Machado (2018) esgota esse tema fundamentando que "o uso gratuito dos recursos naturais tem representado um enriquecimento ilegítimo do usuário, 
pois a comunidade que não usa do recurso ou que o utiliza em menor escala fica onerada." (MACHADO, 2018, p. 85). Deste modo, os custos com a reparação, indenização e punição serão suportados pelo utilizador, mesmo não havendo ilicitudes do agente, este é o princípio do usuario-pagador. Não deve, contudo, ser compreendido citada norma somente com objetivo de reestabelecer em valores ou outra forma de compensaão o bem utilizado, podendo ser interpretado para punição, desde exista manifesta ilicitude do ato ou grave ameaça ao bem e a coletividade.

Contido no princípio do usuário-pagador, ocorre seu desdobramento, o poluidorpagador, "que obriga o poluidor a pagar a poluição que pode ser causada ou que ja foi causada" (MACHADO, 2018, p. 85). O princípio afasta o prejuizo para a coletividade e ao Poder Público, pois não tem o poluidor direito de poluir de forma ilimitada (MACHADO 2018). Derecionando, para o agente poluidor, o dever de proteção, evitando beneficio irrestrito do explorador, devendo quem se aproveita do bem ambiental, investir em tecnologia e prevenção, em prol da coletividade, das presentes e futuras gerações,

Tem caráter punitivo, justificado pela sua relevância social ao proteger o interesse
público e garantir a preservação dos direitos coletivos. A esse instituto, no entanto,
não são consideradas críticas como à referente ao enriquecimento sem causa, tendo
em vista que, nesse caso, a indenização punitiva é destinada a um fundo 'gerido por
um Conselho Federal ou por Conselhos Estaduais de que participarão
necessariamente o Ministério Público e representantes da comunidade, sendo seus
recursos destinados à reconstituição dos bens lesados' (GATTAZ, 2017, p. 5).

Desta forma, é importante frisar que a indenização punitiva, relativa ao dano ambiental, quando estipulada, não irá para uma pessoa específica, mas terá o valor destinado ao Fundo de Proteção dos Direitos Difusos (FDD) ou ao Fundo Nacional Meio Ambiente (FNMA), a depender do julgador. A FDD foi instituída na Lei 7.347/85 trazendo inovação quanto à destinação das indenizações e multas processuais a bens e direitos de interesses difusos e coletivos, esses valores "[...] não irão para pessoas vítimas diretas ou indiretas do prejuízo, mas para o Fundo de Defesa dos Direitos Difusos" (MCHADO, 2018, p. 451), não há de se falar, portanto, em enriquecimento sem causa, visto o destino

De maneira semelhante o Fundo Nacional Meio Ambiente (FNMA) também é instituída pela Lei 7.797 de 1989, com destinação específica de seus fundos ao Meio Ambiente. O fundo visa contribuir para a implementação da PNMA, sendo, financiado por recursos federais, doações, valores recolhidos de multas ambientais ou por outra legislação 
específica, a intenção desse programa é manutenção, aperfeiçoamento e recuperação da qualidade ambiental em conjunto com a participação social.

Ambos os fundos abordados são geridos pelo Poder Público, com participação de um conselho de gestores formado por integrantes do Ministério Público, servidores e cidadãos, impedindo que haja tredestinação ilícita dos recursos de forma ilícita, objetivando cumprir o disposto na PNMA. Assim, analisado o exposto caso, percebe-se que os princípios possibilitam ao juiz a aplicação do dano punitivo diante do caso concreto. Tendo este o dever de proteção das garantias sociais, à luz destes princípios, deve-se interpretá-los da melhor forma possível para aplicar a teoria do desestímulo em nome da proteção do Meio Ambiente.

\section{CONSIDERAÇÕES FINAIS}

Apresentado a pesquisa, conclui-se que ao observar a jurisprudência do STF e do STJ, bem como o histórico ativista da Corte, há a possibilidade de se aplicar a indenização punitiva quando existir dano ao Meio Ambiente, pois, diante da sua fragilidade, e por ser um direito difuso e coletivo, deve ser protegido em razão da presentes e futuras gerações. Assim, na linha de uma aplicação pratica da teoria do ativismo judicial, permite-se aos julgadores, invocando os princípios em auxílio de suas decisões, aplicar a teoria do desestímulo para a redução do dano ambiental e punição pedagógica.

A função do magistrado, diante do caso concreto, é de representar os anseios sociais propostos em uma Constituição ou interpretada diante das mudanças que nela ocorre. Assim, o Ministro relator diante de um caso difícil, como o exposto, que envolve um complexo de elementos e pessoas afetadas, poderia ter estabelecido a indenização punitiva estabelecendo valor indenizatório compensatório e punitivo.

Ao mesmo tempo, cabe ao intérprete jurisdicional promover a proteção ambiental, de modo que aplique os institutos legais e constitucionais, não impondo vedações para a utilização de institutos ou instrumentos que auxiliem o Direito a diminuir o dano causado, se não expressamente vedados. Deve o magistrado estar abertos a novos elementos e estruturas que auxiliem o Meio Ambiente e seu equilíbrio como no caso concreto.

$\mathrm{O}$ estudo da punitive damages permite atualizar o modelo de responsabilidade civil presente atualmente no sistema jurídico do Brasil. Entende-se a punitive damages como uma forma punição pedagógica, distinta da responsabilidade penal e administrativa e, sendo complementar compensação e reparação civil. Nada mais é a indenização punitiva do que um 
valor estabelecido pelo magistrado a danos injustos e de alta gravidade, que atinjam garantidas fundamentais. Deste modo, quando existe violação dos direitos fundamentais, o juiz deve responder com a aplicação de um valor em danos morais que acompanhe tal gravidade, portanto, passível de aplicação do dano punitivo.

A partir do modelo estabelecido por Dworkin de um juiz proativo integrado à Constituição, aos princípios e, sobretudo, ao Direito, em um ativismo judicial, é possível aplicar ao caso concreto a punitive damages, como instrumento de redução do dano ambiental. Portanto, com base no princípios e fundamentos explanados no presente artigo, que convalidariam a viabilidade da indenização punitiva, poderia ter o Ministro relator aceitado a elevação dos danos morais em prol dos direitos fundamentais.

\section{REFERÊNCIAS}

ANTUNES, Paulo de Bessa. Direito Ambiental. 17 ed. São Paulo: Atlas. 2015.

ARAÚJO FILHO, Ministro Raul. Punitive Damages e sua Aplicabilidade no Brasil. Doutrina: edição comemorativa 25 anos, p. 327, 2015.

BARROSO, Luís Roberto. Judicialização, ativismo judicial e legitimidade democrática. (Syn)Thesis . Rio de Janeiro, v. 5, p. 23-32, 2012.

BITTAR, Carlos Alberto. Reparação Civil por Danos Morais. São Paulo: Editora Revista dos Tribunais, 1993.

BOBBIO, Norberto. A Era dos Direitos. Rio de Janeiro: Campus Elsevier, 2004.

BRASIL. Constituição (1988). Constituição da República Federativa do Brasil. Brasília: Senado Federal, Centro Gráfico, 1988.

BRASIL. Lei n. 6.938, de 31 de agosto de 1981. Dispõe sobre a Política Nacional do Meio Ambiente, seus fins e mecanismos de formulação e aplicação, e dá outras providências. Disponivel em: <http://www.planalto.gov.br/>. Acesso em: 18 maio. 2015.

BRASIL. Superior Tribunal de Justiça. Embargos de divergência em Recurso especial n. 1127913. Pedro Yates Porto da Silva e outros versus Bradesco auto/re companhia de seguros e outros. Relator: Ministro Napoleão Nunes Maia Filho. Acórdão publicado no Diário de Justiça da União de 05 de agosto de 2014a. Disponível em: <http://www.stj.jus.br/> Acesso em: 03 de jun. de 2018.

BRASIL. Superior Tribunal de Justiça. Recurso Especial n. 107971. Golden Star Administradora ltda. versus Ministério Público do Estado de Santa Catarina. Relator: Ministro

Revista Brasileira de Filosofia do Direito | e-ISSN: 2526-012X| Porto Alegre | v. 4 | n. 2 |

p. $01-20$ | Jul/Dez. 2018 
Herman Benjamin. Acórdão publicado no Diário de Justiça da União de 18 de agosto 2009. Disponível em: <http://www.stj.jus.br/> Acesso em: 03 de jun. de 2018.

BRASIL. Superior Tribunal de Justiça. Recurso Especial n. 1354536. Maria Gomes de Oliveira versus Petróleo Brasileiro S/A Petrobras. Ministro Relator: Luís Felipe Salomão.

Acórdão publicado no Diário de Justiça da União de 26 de março de 2014b. Disponível em: <http://www.stj.jus.br/>. Acesso em: 03 de jun. de 2018.

CAMPOS, Sergio Pompeu de Freitas. Separação dos Poderes na Jurisprudência do Supremo Tribunal Federal. Primeira Edição. Porto Alegre: Safe - Fabris, 2007.

DWORKIN, Ronald. A conferência Mccorckle de 1984: as ambições do direito para si próprio. Veredas do Direito: Direito Ambiental e Desenvolvimento Sustentável, Belo Horizonte, v. 4, n. 8, fev. 2011. ISSN 21798699. Disponível em:

<http://www.domhelder.edu.br/revista/index.php/veredas/article/view/45/32>. Acesso em: 5 abr. 2018.

DWORKIN, Ronald. Levando os Direitos a Sério. 3 Ed. São Paulo: Martins Fontes, 2010.

DWORKIN, Ronald. O Império do Direito. 3 Ed. São Paulo: Martins Fontes, 2014.

FARIAS, Cristiano Chaves de; BRAGA NETTO Felipe Peixoto; ROSENVALD, Nelson. Novo tratado de responsabilidade civil. Primeira Edição, São Paulo: Atlas, 2015.

GATTAZ, Luciana de Godoy Penteado. Punitive damages no direito brasileiro. Revista dos Tribunais, v. 2017, p. 02-16, 2017.

LEITE, Luciana Wolf. A Responsabilidade Civil e o Dano Punitivo. Revista EJEF, Belo Horizonte: TJMG 1-5p. 2007. Disponível em < https://bd.tjmg.jus.br/jspui/handle/tjmg/8460 > Acessado em: 21 de maio de 2018.

MACHADO, Igor S. Comunidade de princípios e princípio responsabilidade: o juiz Hércules confuso diante de uma natureza ameaçada. Revista Veredas do Direito, Belo Horizonte, v. 13, n. 27, p. 243-265, set./ dez. 2016. Disponível em:

<http://www.domhelder.edu.br/revista/index. php/veredas/article/view/860>. Acesso em: 28 set. 2017.

MACHADO, Paulo Affonso Leme. Direito Ambiental Brasileiro. 23. ed. São Paulo: Malheiros Editores, 2015.

MARTINS-COSTA, Judith; PARGENDLER, Mariana S.. Usos e abusos da função punitiva: punitive damages e o direito brasileiro. Revista CEJ. Brasília: CEJ, n. 28, p. 15-32, 2005.

SCHLESINGER, Arthur M. The Supreme Court: 1947. New York: Time, Inc., 1947. Print.

SERPA, Pedro Ricardo e. Indenização Punitiva. 387 f. (Dissertação de Mestrado em Direito). Faculdade de Direito da Universidade de São Paulo, São Paulo, 2011.

Revista Brasileira de Filosofia do Direito | e-ISSN: 2526-012X| Porto Alegre | v. 4 | n. 2 | p. $01-20$ | Jul/Dez. 2018 
VIANNA, Luiz Werneck; et al. A Judicialização da Política e as Relações Sociais no Brasil. Rio de Janeiro: Revan, 1999. 